\title{
Relationship of Somatic Cell Score and Udder Type Traits of Holstein Cattle
}

Tae Jeong Choi, Kang Seok Seo, Sidong Kim, Byung Ho Park, Je Kwan Choi, Ho Paek Yoon, Seung Hwan Na, Sam Kyu Son, Oh Sub Kwon and Kwang Hyun Cho

National Institute of Animal Science, RDA, 330-801, Rep. of Korea

$$
\text { 체세포점수와 홀스타인 유방형질간의 관계 }
$$

최태정 - 서강석 · 김시동 · 박병호 · 최재관 · 윤호백 · 나승환 · 손삼규 · 권오섭 · 조광현

농촌진흥청 축산과학원

\author{
요 약
}

본 연구는 국제적인 경쟁력을 갖기 위한 젖소개량방법으로 체세포를 활용하는 방법을 모색하고자 선형심사 자료에서 유방염에 관련된 형질을 이용하여 새로운 선발지수를 개발하기 위한 단계로 국내 젖소집단의 체세포점수 분포와 변화추이를 분석해보고 연령, 분만계절, 비유단계의 환경효과를 구명 하고 유방관련 형질과의 유전상관과 유전력을 구하여 기초자료로 활용하고자 본 연구를 진행하였다. 분석은 유우군 능력검정을 통하여 2000년부터 수집된 자료를 이용하였고 자료는 1산차 기록을 갖는 10,929 개체의 290,144 검정일 기록과 37,723 개의 유방형질 기록을 이용하였다. 분석에 이용된 유방형 질은 전유방붙음성, 뒷유방높이, 뒷유방너비, 유방깊이, 앞유두길이의 형질이며 체세포 점수간의 표현 형상관과 유전상관을 구하고 분산성분을 추정하였으며 개체모형을 이용하여 표현형상관과 유전상관 을 분석하였다. 분석에 이용된 모형은 개체모형으로 DF-REML방식을 이용하여 추정하였고 유방깊이 와 앞유두길이의 유전력은 $0.23,0.22$ 로 체세포점수의 유전력은 0.08 로 분석되었다. 유방형질과 체세포 점수간의 표현형상관은 $-0.03 \sim-0.06$ 으로 낮게 나타났으며 높은 유방붙음성을 갖을수록 낮은 체세포 점수를 보였다. 체세포점수와 유방깊이, 체세포점수와 앞유두길이의 유전상관은 부의 상관을 보였다.

(Key words : Somatic cell score, DF-REML, Udder type traits)

\section{I . INTRODUCTION}

The consumer pattern of raw milk, which puts quality first, has altered the hygiene grade of cell counts in developed nations, and hence it dictates other grades based on that standard if the somatic cell counts are more than Denmark and New Zealand countries which give prominence to the qualitative side. Although the new standard of grades was domestically regulated in 2002 through various changes, it has not reached the level of other developed nations. Therefore, it is considered that there should be either an upgrade of the established standard somatic cell count or an abolition of the 4th or 5th grades. In addition, a method of improving somatic cell count should be required, establishing a goal for dairy herd improvement in order to increase our international competitiveness. There is clearly a need to develop a new selection index with traits related

Corresponding author : K. H. Cho, Animal Genetic Improvement Division, National Institute of Animal Science, R.D.A., San 9, Eoryong-ri, Seonghwan-eup, Cheonan-si, Chungnam, 330-801, Rep. of Korea Tel : 041-580-3362, Fax : 041-580-3369, E-mail : ckh1219@rda.go.kr 
to mastitis on the linear type test data. Dairy cattle breeding programs are mainly oriented towards milk production traits, with some consideration toward udder type traits. Genetic improvement of udder conformation may have indirectly diminished the rate of increase in clinical mastitis (Lund et al., 1994). Mastitis is the most costly disease in dairy cattle (Shook and Schutz, 1994) and high SCC in milk affects the price of milk in many payment systems that are based on milk quality (Schukken et al., 1997). Additionally, interest is growing in the evaluation of genetic traits in animals that are resistant to mastitis, but only a few countries include somatic cell count (Heringstad et. al., 2000). Selection of somatic cells was not considered because of low heritability (Emanuelson et. al., 1988; Lund et. al., 1999), but for partial index applications, accurate data for somatic cells is required. According to the guidelines for ICAR, somatic cell count (SCC) in milk samples is obtained using coulter or Fossomatic equipment. Standardized procedures are available from the International Dairy Federation(ICAR guidelines, 2004). In many countries, SCS is used as an indirect selection criterion for improving mastitis resistance (Interbull, 2005), and the ranking and selection of sire affected markedly by SCS were used for genetic evaluation (Heringstad et al., 2006). It is essential to emphasize the importance of somatic cells and to develop new selection criteria using traits related to mastitis. Therefore, we should analyze the relationships among the characteristics that affect the somatic cells in the linear test data. The fundamental reasons that the linear test is conducted is to understand the advantages and disadvantages of functional body characteristics that affect the production of milk, in order to improve production and improve future generations. Methods of utilizing somatic cells should be researched in order to improve milk cattle and thereby improve international competitiveness.
Also, in order to develop an advanced coefficient using the characteristics related to mastitis in the linear test data, this study was conducted to analyze the distribution of somatic cell points of domestic milk cattle groups, to study environmental effects such as age, breeding season, and comparative stages, and to discover the genetic correlation and heritability of genetic characteristics to be used as basic data.

\section{MATERIALS AND METHODS}

\section{Materials}

This study was carried out using data from the Dairy Cattle Improvement Center, National Agricultural Cooperation Federation. The records on first lactations were composed of 290,144 testday records and 37,723 udder type records. Table 1 shows the pedigree structure of the data set. The pedigree file is composed of 424 sires and entities with 15,995 records. 689 grand-sires have records of descendents. The pedigrees as listed in Table 1 were used for the grand-dams.

Somatic cell score (SCS) used in the analyses were lactation means for test day SCC transformed data of dairy cattle from 2000 to 2005. Individual test-day SCC was transformed to the logarithmic scale according to the formula $\log _{2}$ (scc/100,000) +3 (Ali and Shook, 1980).

Table 1. Pedigree structure for the basic data set

\begin{tabular}{lr}
\hline \multicolumn{1}{c}{ Pedigree structure } & Number \\
\hline \hline number of base animals & 17,493 \\
number of animals with records & 15,995 \\
number of sires with progeny records & 424 \\
$\begin{array}{l}\text { number of dams with progeny records } \\
\text { number of grand-sires with progeny }\end{array}$ & 5,933 \\
$\begin{array}{l}\text { records } \\
\text { number of grand-dams with progeny }\end{array}$ & 3,332 \\
\hline
\end{tabular}




\section{Statistical analysis}

Statistical methods were used in the animal model and fixed model. Phenotypic and genetic correlations were estimated between somatic cell count and udder type traits using derivative-free REML (DFREML) : Meyer, K. 1988 using the following model for lactation :

$$
y_{i j k l m}=\mu+h y c_{i}+a_{j}+s_{k}+a n_{l}+e_{i j k l m}
$$

where

hyc $=$ Fixed effect of herd-year-classifier of type evaluation $(\mathrm{i}=1 \cdots 4,812)$

a = Age in month at time of type evaluation $(\mathrm{i}=1 \cdots 4)$

$\mathrm{s}=$ Stage of lactation at time of classification $(\mathrm{k}=1 \cdots 12)$

an $=$ Random effect of additive genetics $(l=1 \cdots$ 17,493)

e $=$ Random residual

The animal model, in which the animal effect was incorporated were used for analysis. The age effects of cows were grouped into 5 month classes $(\mathrm{i}=1 \cdots 4)$ with most of the classifications between 25 months and 29 months of age. Stage of lactation was grouped into 30 day interval of classification classes and were 12. Classifiers were 8 which it take for 10,000 above investigation.

\section{RESULTS AND DISCUSSION}

\section{Environmental effect}

As shown in Table 2, as the age on the evaluation date increased and as the amount of milk through the 305 day period increased, the somatic cell coefficient increased. Seasonally, the spring and summer groups were found to be higher in SCS, but the amount of milk on the 305 day was shown to be relatively less. Groups were divided into four seasons, as per the method used by Degroot et al. (2002). Also, the groups showed significant difference by age, and showed the same results as Singh and Ludri (2001) but the seasonal effect was not inserted in the analysis model because only the first group showed significance.

Generally, as the age and lactation stage advanced, the number of somatic cells increased, but it is known that the number of somatic cells increases regardless of the mastitis infection at the late pregnancy stage or at the early stage of post-parturition of dairy cattle. Schepers et. al. (1997) showed that stage of lactation affected the SCC. As shown in Table 3, stage of lactation had a pronounced effect on milk SCC, with the level being high in early lactation, low in mid-lactation and high again in late lactation. Also, Rodriguez-Zas et. al. (2000) reported that milk SCS typically reaches a minimum early in

Table 2. Analysis of SCS and total milk in 305 days by age, season effect in four groups.

\begin{tabular}{ccccc}
\hline \multirow{2}{*}{ Group } & \multicolumn{2}{c}{ Age $^{1)}$} & \multicolumn{2}{c}{ Season $^{2)}$} \\
\cline { 2 - 5 } & SCS & Milk305 & SCS & Milk305 \\
\hline \hline 1 & $2.84 \pm 0.01$ & $8207.97 \pm 15.61$ & $3.076 \pm 0.02$ & $8460.08 \pm 20.49$ \\
2 & $2.90 \pm 0.01$ & $8458.67 \pm 12.41$ & $2.955 \pm 0.02$ & $8265.50 \pm 20.47$ \\
3 & $2.95 \pm 0.02$ & $8629.26 \pm 24.96$ & $2.906 \pm 0.02$ & $8580.24 \pm 20.02$ \\
4 & $3.18 \pm 0.04$ & $8633.96 \pm 39.73$ & $2.938 \pm 0.01$ & $8624.03 \pm 18.74$ \\
\hline
\end{tabular}

Age $^{1)}$ 1: age $=<24$ 2: $25=<$ age $=<29$ 3: $30=<$ age $=<34$ 4: $35=<$ age

Season $^{2)} 1$ : Mar.-May 2 : Jun.-Aug. 3 : Sep.-Nov. 4 : Dec.-Feb 
Table 3. Means and standard deviation of lactation stage effect and stage test group

\begin{tabular}{lrrcccc}
\hline Variable & \multicolumn{1}{c}{$\mathrm{N}$} & Mean & SD & Stage group & $\mathrm{N}$ & SCS \\
\hline \hline Stage 1 & 78,381 & 2.52 & 1.67 & 1 & 57,516 & 2.75 \\
Stage 2 & 145,239 & 2.62 & 1.57 & 2 & 56,633 & 2.61 \\
Stage 3 & 65,574 & 2.86 & 1.54 & 3 & 57,569 & 2.76 \\
Stage 4 & 950 & 2.97 & 1.47 & 4 & 58,161 & 2.85 \\
& & & & 5 & 47,855 & 2.94 \\
& & & 6 & 2,109 & 2.98 \\
\hline
\end{tabular}

stage1 $(1=<$ lactation day $=<90)$, stage2 $(91=<$ lactation day $=<240)$, stage3 $(241=<$ lactation day $=<310)$, stage4 (311 = < lactation day), $1(1=<$ lactation day $<60), 2(60=<$ lactation day $<120), 3(120=<$ lactation day $<$ 180), $4(180=<$ lactation day $<240), 5(240=<$ lactation day $<305), 6(305=<$ lactation day $)$

lactation then increases as lactation progresses.

Moreover, interest in the evaluation of genetic traits that are resistant to mastitis is on the rise, but only a few countries include somatic cell count. Most research into genetic evaluation for mastitis has concentrated on the use of somatic cell count (SCC) instead of actual records of clinical mastitis incidence. Direct selection of somatic cells was not considered due to low heritability. However, in order to be applied index partially, it is believed that an accurate data gathering of somatic cells should be carried out. The genetic evaluation of somatic cells was introduced in the U. K in 1998. In the study, the single trait model was used for analysis (Mrode et al., 1998).

\section{Estimate of variance component}

According to Chu and Shi (2002) the average UD (udder depth) was 27.7, which was relatively lower hocks and this is presented in Table 4. Heritability of udder traits and total score of linear type test and somatic cell score (Table 4) were high for udder depth (0.239) and front teat length (0.224) but other traits estimated showed very low heritability. The heritability 0.082 for SCS was higher than the heritability of 0.027 in the first lactation as reported by Mangwiro in 2000. However, the result was similar to the heritability of 0.087 for the second parity. According to the report by Boettcher et al. in 1998, the heritability of the udder depth and

Table 4. Estimates of variance component of udder traits and somatic cell score

\begin{tabular}{cccccc}
\hline Variable & Mean & SD & $\sigma_{P}^{2}$ & $\sigma_{E}^{2}$ & $\mathrm{~h}^{2}$ \\
\hline \hline FUA & 24.20 & 6.97 & 35.66 & 33.22 & 0.068 \\
RUH & 23.04 & 7.72 & 39.04 & 36.20 & 0.072 \\
RUW & 20.57 & 6.65 & 29.57 & 28.21 & 0.045 \\
UC & 25.13 & 6.29 & 30.78 & 29.38 & 0.045 \\
UD & 28.26 & 6.84 & 34.52 & 26.23 & 0.239 \\
FTL & 23.00 & 7.38 & 49.13 & 38.08 & 0.224 \\
SCS & 2.89 & 1.53 & 2.06 & 1.89 & 0.082 \\
\hline
\end{tabular}

$\mathrm{P}^{2}$ : Phenotypic variance, $\mathrm{R}^{2}$ : Residual variance, $\mathrm{h}^{2}:$ Heritability

FUA (Fore udder attachment), RUH (Rear udder height), RUW (Rear udder width), UC (Udder cleft),

UD (Udder depth), FTL (Front teat length) 
front teat length were 0.26 and 0.21 , respectively; studies published later confirmed the results of this study. Generally, genetic improvement of teat placement, length of fore udder and udder depth has a positive effect on udder health, measured as lowering of SCC (Monardes et al. 1990, Rogers et al. 1991).

The average fore udder attachment was 24.20 points, maintaining an average strength, and the rear udder height and rear udder width were 23.04 points and 20.57 points, on average. Udder cleft and udder depth were 25.13 points and 28.26 points, respectively, showing a depth of 3 $\mathrm{cm}$ and about $5 \mathrm{~cm}$ of udder depth. Front teat length was 23.00 points, showing about $5.7 \mathrm{~cm}$ of teat length, on average. The somatic cell coefficient was 2.89, showing less than 100,000 (cells/ml).

Genetic correlations between linear type traits and SCC are needed to properly evaluate the usefulness of selection for improved udder characteristics to reduce mastitis or slow the increase in mastitis associated with increase yield (Rogers, 1993). Total milk yield in 305 days was estimated to have genetic correlations between udder depth $(-0.19), 0.33$ with rear udder width and total score (Table 5). Teat length is positively correlated with total milk yield in 305 days and also with SCS. Genetic correlations between

Table 5. Genetic correlations between somatic cell score (SCS) and 305d adjustment milk and type traits of related udder in Holsteins

\begin{tabular}{lcc}
\hline \multicolumn{1}{c}{ Type trait } & Milk305 & \multicolumn{1}{c}{ SCS } \\
\hline \hline Fore udder attachment & 0.131 & $-0.037^{*}$ \\
Rear udder height & 0.158 & $-0.039^{*}$ \\
Rear udder width & 0.330 & $-0.005^{\mathrm{NS}}$ \\
Udder cleft & 0.054 & $-0.047^{*}$ \\
Udder depth & -0.191 & $-0.069^{*}$ \\
Front teat length & 0.025 & $0.010^{\mathrm{NS}}$ \\
\hline
\end{tabular}

P-value : * if $\mathrm{p}<0.01$, NS if $\mathrm{p}>0.05$ somatic cell score and type traits are negative except the estimate for the front teat length. Teat length should be uniform because too big or too small teats not only badly fits to the milking cup but also affect the somatic cell count.

When the genetic variance and residual variance of the SCS were calculated using the characteristics with udder traits of high heritability, the udder depth was shown to be relatively low. Selection for lower somatic cell scores, higher udders, and closer teat placement would help to reduce or to eliminate undesirable correlated responses in milking labor and mastitis associated with selection for increased milk yield (Rogers, 1993).

Longer teats were associated with higher SCC, which agree with the results from Seykora and McDaniel (1985). Perhaps longer teats are more prone to injury due to housing, handling, and milking machine incompatibility (Rogers et al., 1991). The udder depth, as a result of genetic variance and residual variance of SCS traits with high heritability among udder traits, demonstrated more or less small differences. The phenotypic correlation between UD and SCS was -0.07 but the genetic correlation appeared as -0.53 . Moreover, the genetic correlation between FTL and SCS indicated 0.02 (Table 6).

Teat length is also positively correlated with SCS, as described by Boettcher et al. (1998) who reported a value of 0.05, and Rupp and Boichard (1999) who reported a value of 0.08 . It indicated

Table 6. Heritability (on diagonal) and phenotypic (above diagonal) and genetic (below diagonal) correlations among the traits in first parity

\begin{tabular}{lrrr}
\hline Traits & $\begin{array}{c}\text { Udder } \\
\text { depth }\end{array}$ & $\begin{array}{c}\text { Front teat } \\
\text { length }\end{array}$ & SCS \\
\hline \hline Udder depth & 0.23 & -0.07 & -0.07 \\
Front teat length & -0.04 & 0.22 & 0.02 \\
SCS & -0.53 & 0.03 & 0.08 \\
\hline
\end{tabular}


a slightly smaller correlation, unlike the result reported in foreign countries. The genetic correlation of the UD was shown to be -0.26 according to the report of Boettcher et al. (1998), but the result of this study is -0.53 , showing a significant difference. Phenotypic correlations between UD and SCS had -0.07. Although the phenotypic correlation between the UD and SCS was -0.07 , the genetic correlation was -0.53 and the genetic correlation between the FTL and SCS was -0.04 . Udders should be well attached to support more milk without functional problems.

\section{Analysis of somatic cell score on udder} traits by linear score

The individual traits of measurement were applied uniformly for all traits on a scale of 1 to 50.

Some udder characteristics are genetically related to SCS. Selection for higher and more tightly attached udders should reduce or slow the increase in SCC from selection for increased milk yield (Rogers et al., 1991).

Phenotypic correlations between udder traits and SCC were variable but cows with higher udder depth scores (higher udders) had lower SCC (Rogers et al., 1991). Higher scores for the various udder traits represent tighter udder attachments, deeper udder clefts, higher udders, and longer teat lengths (Rogers and Hargrove, 1993). When the difference in somatic cell coefficients was compared and analyzed according to the characteristics related to the udder and teat, the SCS tended to decrease as the points for the FUA, UC, UD, and FTL increased (Table 7). However, the SCS was high at the highest points for the rear udder height and rear udder width. The above results showed that excess height and width of udder could cause some problems. The linear scores are grouped according to the special distribution of preference score.

The average of the total final scores was 74 points, with 2.60 for the SCS. It was shown that as the linear test score increased, the SCS coefficient decreased (Table 8). When the Duncan test was conducted for each group, there were significant differences. It could be said that entities with good phenotypic characteristics are highly resistant to mastitis. Additionally, it is believed that weight should be considered for the phenotypic characteristics or comprehensive points for udders for the KTPI (Korean Type Production Index), which was used for evaluating the genetic capabilities.

Table 7. Means and standard deviation of SCS for type traits in relation to udder in linear score

\begin{tabular}{ccccccc}
\hline $\begin{array}{c}\text { Linear } \\
\text { Score }\end{array}$ & FUA & RUH & RUW & UC & UD & FTL \\
\hline \hline $1 \sim 4$ & $2.81 \pm 1.78$ & $2.95 \pm 1.63$ & $2.79 \pm 1.73$ & $3.05 \pm 1.76$ & $2.88 \pm 1.63$ & $2.73 \pm 1.68$ \\
$12 \sim 18$ & $2.70 \pm 1.62$ & $2.67 \pm 1.61$ & $2.65 \pm 1.58$ & $2.71 \pm 1.60$ & $2.73 \pm 1.63$ & $2.64 \pm 1.58$ \\
$22 \sim 28$ & $2.59 \pm 1.58$ & $2.59 \pm 1.57$ & $2.59 \pm 1.58$ & $2.59 \pm 1.57$ & $2.62 \pm 1.59$ & $2.60 \pm 1.59$ \\
$32 \sim 38$ & $2.56 \pm 1.58$ & $2.54 \pm 1.58$ & $2.54 \pm 1.61$ & $2.54 \pm 1.61$ & $2.54 \pm 1.56$ & $2.59 \pm 1.58$ \\
$45<$ & $2.37 \pm 1.59$ & $2.63 \pm 1.64$ & $2.62 \pm 1.69$ & $2.37 \pm 1.71$ & $2.42 \pm 1.60$ & $2.57 \pm 1.66$ \\
\hline
\end{tabular}

FUA : Fore udder attachment, RUH : Rear udder height, RUW : Rear udder width, UC : Udder cleft, UD : Udder depth, FTL : Front teat length; 
Table 8. Test of significance and mean of somatic cell score on final score group

\begin{tabular}{cccc}
\hline $\begin{array}{c}\text { Final } \\
\text { Score }\end{array}$ & Mean & SD & Duncan \\
\hline \hline $52 \sim 60$ & 2.88 & 1.81 & $\mathrm{~A}$ \\
$61 \sim 70$ & 2.74 & 1.67 & $\mathrm{~B}$ \\
$71 \sim 80$ & 2.60 & 1.58 & $\mathrm{C}$ \\
$81<$ & 2.38 & 1.47 & $\mathrm{D}$ \\
\hline
\end{tabular}

\section{CONCLUSION}

The objective of this study was to examine the correlation between fore udder attachment, rear udder height, rear udder width, udder cleft, udder depth, and somatic cell score (SCS) of Holsteins in Korea. Generally phenotypic correlations were very low between udder traits and lactation SCS which varied from 0.03 to -0.06 . Heritability of all type traits and SCS were all less than 0.12. Phenotypic correlations between udder traits and SCS and udder depth score (higher udders) had lower SCS. Genetic correlations between SCS and udder depth, SCS and front teat length were negative. Heritability of SCS was $0.08,0.23$ for udder depth and 0.22 for front teat length. From the result of this study, there is no phenotypic correlation between udder traits and lactation SCS. However, they were genetically related. Therefore this study should be continuously carried out for future genetic evaluations.

\section{ABSTRACT}

Data were taken from the dairy herd improvement program from the year 2000, composed of 10,929 first lactation cows consisting of 290,144 test-day records and 37,723 udder type records. The objective of the study was to estimate genetic and phenotypic correlation between fore udder attachment, rear udder height, rear udder width, udder cleft, udder depth, and somatic cell score (SCS) and to calculate heritability of udder depth, front teat length and SCS in Holstein cattle in Korea. The variance component estimation using test day model was determined by a derivative-free algorithm-restricted maximum likelihood (DF-REML) analysis method. Generally phenotypic correlations were very low between udder traits and lactation SCS which varied from -0.03 to -0.06 . Heritability of all type traits and SCS was smaller than 0.12 . The results of this study would be applicable to SCS using linear genetic evaluation for future studies.

\section{REFERENCES}

1. Ali, A. K. A. and Shook, G. E. 1980. An optimum transformation for somatic cell concentration in milk. J. Dairy Sci. 63:487-490.

2. Boettcher, P. J., Dekkers, J. C. M. and Kolstad, B. W. 1998. Development of an udder health index for sire selection base on somatic cell score, udder conformation, and milking speed. J. Dairy Sci. 81:1157-1168.

3. Chu, M. X and Shi, S. K. 2002. Phenotypic factor analysis for linear type traits in Beijing Holstein cows. Asian-Aust. J. Anim. Sci. Vol. 15 No. 11:1527 .

4. De Groot, B. J., Keown, J. F., Van Vleck, L. D. and Marotz, E. L. 2002. Genetic parameters and responses of linear type, yield traits and somatic cell scores to divergent selection for predicted transmitting ability for type in Holsteins. J. Dairy Sci. 85:1578-1585.

5. Emanuelson, U., Danell, B. and Philipson, J. 1988. Genetic parameters of clinical mastitis, somatic cell counts, and milk production estimated by multiple trait restricted maximum likelihood. J. Dairy Sci. 71:467.

6. Heringstad, B., Klemetsdal, G. and Ruane, J. 2000. Selection for mastitis resistance in dairy cattle-a review with focus on the situation in the 
Nordic countries. Livest. Prod. Sci. 64:95-106.

7. Heringstad, B., Gianola, D., Chang, Y. M., Ødegård, J. and Klemetsdal, G. 2006. Genetic associations between clinical mastitis and somatic cell score in early first-lactation cow. J. Dairy Sci. 89:2236-2244.

8. Lund, M. S., Jensen, J. and Petesen, P. H. 1999. Estimation of genetic and phenotypic parameters for clinical mastitis, somatic cell production deviance, and protein yield in dairy cattle using Gibbs sampling. J. Dairy Sci. 82:1045-1051.

9. Lund, T., Miglior, F., Dekkers, J. C. M. and Burnside, E. B. 1994. Genetic relationships between clinical mastitis, somatic cell count, and udder conformation in Danish Holsteins. Livest. Prod. Sci. 39:243-251.

10. Mangwiro, F. K., Mhlanga, F. N., Dzama, K. and Makuza, S. M. 2000. Genetic evaluation of somatic cell counts of Holstein cattle in Zimbabwe. Asian-Aust. J. Anim. Sci. Vol. 13 No. 10:1347.

11. Meyer, K. 1988. DFREML-a set of programs to estimate variance components under an individual animal model. J. Dairy Sci. 71(Suppl. 2):33.

12. Monardes, H. G., Cue, R. I. and Hayes, J. F. 1990. Correlations between udder conformation traits and somatic cell count in Canadian Holstein cows. J Dairy Sci. 73:1337-1342.

13. Mrode, R. A., Swanson, G. J. T. and Winters, M. S. 1998. Genetic parameters and evaluations for somatic cell counts and its relationship with production and type traits in some dairy breeds in the UK. Anim. Sci. 66:569-576.

14. Rogers, G. W. 1993. Index selection using milk yield, somatic cell score, udder depth teat placement, and foot angle. J. Dairy Sci. 76:664670 .

15. Rogers, G. W. and Hargrove, G. L. 1993. Absence of quadratic relationships between genetic evaluations for somatic cell scores and udder linear traits. J Dairy Sci. 76: 3601-3606.

16. Rogers, G. W., Hargrove, G. L., Jr. Lawlor, T. J. and Ebersole, J. L. 1991. Correlations among linear type traits and somatic cell counts. J Dairy Sci. 74:1087-1091.

17. Rupp, R. and Boichard, D. 1999. Genetic parameters for clinical mastitis, somatic cell score, production, udder type traits, and milking ease in first lactation Holsteins. J. Dairy Sci. 82:21982204.

18. Rodriguez-Zas, S. L., Gianola, D. and Shook, G. E. 2000. Evaluation of models for somatic cell score lactation patterns in Holsteins. Livest. Prod. Sci. 67:19-30.

19. Schepers, A. J., Lam, T. J. G. M., Schukken, Y. H., Wilmink, J. B. M. and Hanekamp, W. J. A. 1997. Estimation of variance components for somatic cell counts to determine thresholds for uninfected quarters. J Dairy Sci. 80:1833-1840.

20. Schukken, Y. H., Lam, T. J. E. M. and Barkema, H. W. 1997. Biological basis for selection on udder health traits. INTERBULL Bull. No 15: page 27-33.

21. Seykora, A. J. and McDaniel, B. T. 1985. Heritabilities of teat traits and their relationships with milk yield, somatic cell count, and milk production. J. Dairy Sci. 69:2395.

22. Shook, G. E. and Schutz, M. M. 1994. Selection of somatic cell score to improve resistance to mastitis in the United States. J. Dairy Sci. 77: 648-658.

23. Singh, Mahendra and Ludri, R. S. 2001. Influence of stages of lactation, parity and season on somatic cell counts in cows. Asian-Aust. J. Anim. Sci. Vol. 14 No. 12:1775.

(접수일자 : 2007. 11. 12. / 수정일자: 2008. 5. 26. / 채택일자 : 2008. 6. 2.) 